\title{
PRE-PUBLICATION DRAFT
}

\section{A Clash of Harmony}

Forgery as Politics in the Work of Thomas Chatterton

Ivan Phillips, University of Hertfordshire

Thomas Chatterton killed himself at the age of seventeen. It is generally believed that he committed suicide in a fit of artistic or adolescent or economic despondency, but it now seems more likely that he overdid the vitriol whilst treating himself for gonorrhea. If we can overlook the occasional background whispers about foul play (who?) or the rockand-roll notion of a staged exit (why?), we can state with confidence that Thomas Chatterton killed himself at the age of seventeen, either by terrible accident or desperate design. ${ }^{1}$ And this is where the problems begin. Because 'this chameleonlike being, ${ }^{2}$ the phrase comes from his least unreliable biographer, E. H. W. Meyerstein - is at the centre of a cultural disturbance that continues to expand into critical space, either distorting him through iconic magnification or blanking him out altogether. 'The axis of the dark machine,' he writes in 'Journal $6^{\text {th }}$, 'Is enigmatic and unseen.' This richly suggestive couplet might supply an emblem for both the ideological motivations of the Chatterton mythology and the subtler operations of the work it has eclipsed. ${ }^{3}$

When he died in August 1770, Chatterton left behind a massive body of 'acknowledged' poems, letters, sketches, dramas and essays, and an only slightly smaller body of poems, letters, sketches, dramas and essays purporting to be by (or translated from) a cast of historical figures ranging from the Saxon monk Turgot to the fifteenth-century knight, John Iscamme. The former have rarely been anyone's concern, whereas the latter - the so-called 'Rowley' pieces, named after their most prominent 
voice, the monk Thomas Rowley - were the stuff of learned dispute and extravagant enthusiasm (though precious little critical analysis) almost before the author was cold in his workhouse lime-pit. Any critic drawn to the supposed gap in the Chatterton oeuvreauthentic but dull on one side, forged and fascinating on the other - might be forgiven for concluding that there are only two things getting in the way of a satisfactory analysis of the life and the work: the life (more particularly the death) and the work. Chatterton has become the literary-critical equivalent of an echo-chamber, an imaginary location in which identities merge and voices scramble. Until comparatively recently, the location was well-known but largely unvisited, perhaps because it was perceived to be as much of a threat as a challenge. 'For the critic,' Nick Groom has written,

Chatterton is too mercurial, too confusing: perpetually challenging the genres of writing, mixing national histories, national fictions, and national myths in a great post-Enlightenment reinvention of the past. ${ }^{4}$

This sequestration of Chatterton must go beyond any critical nervousness about formal complexity or the vulnerability of national narratives: such vulnerability is, after all, at the heart of contemporary literary studies and, complex though Chatterton undoubtedly is, he is no more so than, say, William Blake or James Joyce. Clearly, there is the squeamishness that has always refused the forger the status of artist, and the snobbery that resists the idea that a teenager might actually write something worth reading. ${ }^{5}$ But there is more to the neglect of Chatterton than this, something that touches upon the peculiar romantic pathology of Western culture. His tragic corpse has become his most popular work of art, his only canonical piece, and it seems to manifest something of the destructive cultural phenomenon identified by Walter Benjamin in 1935: '[Humanity's] self-alienation has reached such a degree that it can experience its own destruction as an 
aesthetic pleasure of the first order. ${ }^{6}$ Jean Baudrillard quotes this passage in Symbolic Exchange and Death, extending the terms of Benjamin's diagnosis beyond its immediate concern with the growth of European fascism to encompass a more general morbidity. ${ }^{7}$ Considering the persistent allure of Chatterton's imagined death scene, it might also reflect the growth of Guy Debord's society of spectacle, a world of uninterpretable theatre and mediated effects: Wordsworth's 'marvelous Boy' has become, in many ways, the first rock and roll suicide, whether he meant to kill himself or not. ${ }^{8}$ This makes a tantalising link between recent cultural myths of willing or accidental self-destruction and those which excited the romantic imagination from the late-eighteenth century onwards, most obviously in works such as Goethe's Sorrows of Young Werther (1774) and Byron's Manfred (1817), but also in the writings of William Hazlitt. ${ }^{9}$ In relation to Chatterton, the distinctly political element of Benjamin's thesis is worth keeping in mind, the iconography of the youthful dead poet - the forgery of the forger - becoming a repetitive spectacle haunted by ideology.

The age in which Chatterton wrote has been characterised by M. H. Abrams as the age of pragmatics, an age in which the moral imperatives of art - to teach, to delight, to move - implied boundaries and decorum. ${ }^{10}$ It is no coincidence, then, that it was also the age of canon-building and textual ownership. During Chatterton's short lifetime Samuel Johnson published his Dictionary of the English Language (1755) and Thomas Percy published his Reliques of Ancient English Poetry (1765). Within ten years of the boy's death, both Thomas Warton's three-volume History of English Poetry (1774-81, which featured Rowley) and Johnson's Lives of the Most Eminent English Poets (177981, which didn't) had begun to appear. An Act of 1709 had, for the first time, fixed the 
publication rights of authors within law (fourteen years, renewable until death). This was still being debated well into the nineteenth century. Such attempts to regulate and clarify were bound to muddy the waters in an interesting way, and so it was also a golden age of literary forgeries, of Ossian and Otranto. ${ }^{11}$ But as Groom has argued, the Rowley works are not simply invented texts, they are complex tactile and visual objects which revolt against print culture because they are both chimerical - they are forgeries of things which never existed - and unrepeatable:

Rowley attempted to find or construct a place outside the all-pervasive culture of typography, and therefore insisted on all the untypographic elements of the medium: calligraphy, ink, paper or parchment, as well as provenance, damage, and supplementarity. They forced print to insist and re-insist upon its totalitarianism, because these untranslatable aspects of the manuscript exposed the absolutist assumptions of typography. ${ }^{12}$

In such a reading, the Rowleyan creations appear to constitute an intricate formal satire on the processes of remediation that Jay David Bolter and Richard Grusin have traced into the digital age, and that had prior articulation in Marshall McLuhan's notion of media hybridity. ${ }^{13}$

McLuhan, for all the contentiousness of his ideas, can offer suggestive ways of thinking about the powerfully anomalous condition of Chatterton's impostures. In particular, his theorising in relation to the 'psychic' effects of printing seems to resonate with the rich interplay of material, imagistic and scriptorial elements in the Rowley work: 
Like any other extension of man, typography had psychic and social consequences that suddenly shifted previous boundaries and patterns of culture. In bringing the ancient and medieval worlds into fusion - or, as some would say, confusion - the printed book created a third world, the modern world... ${ }^{14}$

McLuhan's insistence on the specificity of manuscript and print media - 'Typography was no more an addition to scribal art than the motorcar was an addition to the horse ${ }^{15}$ - indicates what is materially distinct about Chatterton's forgeries and suggests the degree to which they are diminished when they are printed as plain poetic text. Even where the idiosyncracies of spelling and sense are largely respected (Donald S. Taylor, Grevel Lindop), not 'tidied up' or bowdlerised (Thomas Tyrwhitt, Walter Skeat, John Richmond), the graphical and physical particularities are inevitably lost, often replaced by the smothering encrustation of academic apparatus. ${ }^{16}$ To read Rowley's poems as poems - to encounter his manuscript prose writings as printed text - is not to lose their significance, but to transform it. This is not unique to the Rowley works, of course: it is true of any manual production converted to a mechanical or digital form of representation. ${ }^{17}$ The handwritten original of one of Chatterton's acknowledged writings - or one of Sir Thomas Wyatt's or Emily Dickinson's or Basil Bunting's or W.H. Auden's - is changed by its translation into print, just as the Mona Lisa becomes something else when it is adapted to a postcard or Picasso's Guernica when it stands as a figure in a textbook or Anthony Gormley's The Angel of the North when it appears within a website. The Rowley creations are uniquely complicated and problematised in this respect though, and their capacity (even unseen) to draw critical attention to the act of representation and to the profound semiotic effects of remediation between forms, is a major indicator of their significance: 
When a literary work interrogates the inscription technology that produces it, it mobilizes reflexive loops between its imaginative world and the material apparatus embodying that creation as a physical presence. ${ }^{18}$

N. Katherine Hayles' definition of 'technotexts' - evolved in relation to Talan Memmott's web hyperfiction Lexia to Perplexia (2000), Tom Phillips' 'treated Victorian novel' A Humument (1970-2004) and Mark Z. Danielewski's metafictional House of Leaves (2000) - might almost have been formulated to describe the cultural operation of the eighteenth-century schoolboy forger. ${ }^{19}$

In the past, Benjamin argues in 'The Work of Art in the Age of Mechanical Reproduction', original artworks were able to maintain a pristine identity, with handmade reproductions being easily dismissed as forgeries. With mechanisation and precision of reproduction, the 'aura' of originality faded, a work of art could be copied, modified, moved, disseminated. ${ }^{20}$ The works of Thomas Rowley and his associates within Chatterton's corpus, created on a fault-line between the manuscript age and the print age, seem to both confirm and transcend Benjamin's schema. Forgeries in the strictest sense, reproductions of nothing, they are ready-mades that were assembled but never found, neither copies nor - according to any traditional understanding - originals. At the same time they are one-offs, truly unique, transmissible only at the level of bare text. These scraps of childishly distressed parchment, singed and sooty, waxy, ragged, ink-blotted, fragile, resist reproduction because something will always be missing from any facsimile. Try to process a sample of Rowleyan English in Microsoft Word and the screen will very soon become a tangle of red and green dubiety: a twenty-first century spellchecker is even less comfortable with the lawless eccentricities of Chatterton's middle English than were the lexicographers and antiquarians of the late-eighteenth and nineteenth centuries. The language continues, in other words, to sabotage attempts at 
standardisation, impossible to either absorb or subdue. Analogous to digital artefacts in the current age in the sense that it evades its own origins, the Rowley corpus also casts doubt on attempts by museums and universities to digitise old manuscripts in the name of access and conservation. Its scattered fragments show both the vulnerability and the power of the manuscript as cultural object. They are critically neglected, subsumed into the mythology of the teenage poète maudit. They rarely see daylight and some of them will never be legible again. Their aura is undeniable. More than that, it is invulnerable to decay. The Rowley works are, perhaps, the ultimate examples of what N. Katherine Hayles has termed 'material metaphors', objects in which 'the materiality of inscription thoroughly interpenetrates the represented world' and 'whose physical properties and historical usages structure our interactions with [them] in ways obvious and subtle'. ${ }^{21}$

Chatterton's forgeries are subversive anachronisms, constituting an unknowable, uncontainable mass in an era of empiricism and containment. Furthermore, in the Gutenberg galaxy of McLuhan, where meaning becomes a distraction from medium, where content seems to be separable from form, their emphasis on surface qualities has a power beyond that of a crude teenage joke. ${ }^{22}$ The Rowley manuscripts are authentic but faked, extant but lost from view, ancient but modern - perhaps even postmodern, if we take that term to refer to a style rather than an epoch. In cultural terms, this makes them dangerous: they are anomalous and unstable.

Much has been made in the past of Chatterton as a poet with an upstart and mercenary agenda, a young man on the make who killed himself when pranks, poetry and politics failed to pay the rent. The cynical fragment, 'Interest, thou universal god of men', would seem to support this view: 
Can honest consciousness of doing right

Provide a dinner or a bed at night?

What though Astrea decks my soul in gold,

My mortal lumber trembles with the cold;

Then, cursed tormentor of my peace, begone!

Flattery's a cloak, and I will put it on.

Comments in a letter to his sister, written to Bristol from London as he tried to make his mark as a freelancing liberal journalist, might cast further suspicions over his authorial integrity. He had been in the capital for less than a month and - on the strength of an essay written for 'Wilkes and Liberty' - had secured an introduction to the Lord Mayor, William Beckford:

But the devil of the matter is, there is no money to be got on this side of the question. Interest is on the other side. But he is a poor author, who cannot write on both sides. (30 May 1770)

But to take Chatterton at his word here (or anywhere), to take him literally, is to risk falsification or simplification of the work. He is, at all times, a writer of innuendo and dissenting ironies - or a 'sad lyar' as the early Chatterton scholar, the Rev. Michael Lort, puts it. ${ }^{23}$ 'A character is now unnecessary,' he had written to his mother a few weeks earlier, 'an author carries his character in his pen.' (6 May 1770) Intention becomes more than a fallacy when the author is as polyphonic and elusive as Chatterton. Like Keats, the Romantic whose background was most like his own and who was to feel his influence most directly, he shows what Christopher Caudwell - 
writing in the 1930s - referred to as 'the marks of commodity-production', the strains of the poet's position as a 'producer for the free market': the Rowleyan style, like the courtly idiom of Keats, responds not to feudal but to bourgeois pressures. ${ }^{24}$ Literary biography - that most bourgeois of forms, wary of politics, even more wary of style has relished the distraction of a performing monkey, but ignored the performance itself. And as now seems likely, Chatterton was not starving at the time of his death: he was actually doing rather well. ${ }^{25}$

Chatterton was a free-thinking, lower-class youth who had grown up on the edge of the south Bristol coal fields, exploring the cool Anglican shadows of the church of St Mary Redcliffe, the symbolic lodestone of his imagination, at the same time as experiencing the open-air enthusiasms of George Whitfield and John Wesley. ${ }^{26}$ His poetry includes attacks on both the established church and Methodism, and it seems reasonable to accept Donald S. Taylor's designation of his political sympathies as uneasily but instinctively 'on the left'. ${ }^{27}$ His apparent willingness to play the shapeshifter in his journalism can be attributed to both the exigencies of the moment (the old school snobberies of the literary world, suppression of the radical presses, the sudden death of Beckford) and the restlessness of his style. This, Louise J. Kaplan has argued, might have had its origins in the internalised trauma of fatherlessness, the elder Thomas Chatterton (a chorister, writer of pub songs and dabbler in the occult) having died three months before his son's birth:

The significant issues concern the unique and puzzling relationships between Chatterton's acknowledged freethinking writings and the conflicts expressed in his imposturous works, which were noble, pure, and saintly. ${ }^{28}$ 
Despite a tendency to overplay pathology at the expense of poetics, Kaplan's speculations are compelling. Narcissism, manic depression and 'the humiliation of oedipal defeat ${ }^{29}$ might, very likely, have informed the particular antagonisms and circumventions of Chatterton's work, not only the adoption of masks and poses, but also the pornographic shock-tactics of pieces such as 'The Exhibition' (his notorious satire about a well-endowed flasher) and 'The Letter Paraphras'd':

By God I want a strapping Man

My cunt is more than twice a Span

And Faith I speak it without Joking

Last Night I put a Cartwheel Spoke in...

Kaplan notes that such a boisterous piece of misogynistic unpleasantness - in this case a never-delivered retort to a letter of rejection from a girl who had wished him a 'good Gonery' - is not untypical of either adolescent boys or of the age in which it was written. (She goes so far, in fact, as to suggest that it reflects 'the concern of all men, in all places, in all eras'.) But Meyerstein's awareness of Chatterton's deep-seated and immoderate desire to épater le bourgeois seems equally relevant here, suggesting how these dirty jokes form an assault against civil propriety and the gentility of official discourse. $^{30}$ Again, this is nothing unusual in the youthful male - teenage kicks, rebellion without a cause, it is a version of the obscene graffiti that can be found on school-desks and on the walls of public toilets, underpasses and Facebook - but the rough angry laughter of these poems reverberates through Chatterton's most sophisticated work.

In search of psychological causation, Kaplan concentrates on the self-evidently displaced or coded works of Rowley, and tends to endorse the confessional transparency 
of the acknowledged writings. These - described by Groom as 'aberrant works in the canon of a forger ${ }^{, 31}$ - have generally fared badly in discussions of the work, but, as I have already implied, the tendency to split Chatterton down the middle might be a critical error. In particular, it tends to erode the political dimensions of the work, dissolving the links between mediaevalist imposture and evasive nonconformity.

In a letter to his friend Thomas Carey, written from London a month before his death, Chatterton compares the playing styles of two Bristolian organists, Robert Broderip and John Allen, using the distinctly Rowleyan symbol of ecclesiastical stonework:

Broderip has no taste, at least no real taste. Step into Redcliff Church, look at the noble arches, observe the symmetry, the regularity of the whole; how amazing must that idea be which can comprehend at once all that magnificence of architecture; do not examine one particular beauty or dwell upon it too minutely, take the astonishing whole into your empty pericranium, and then think, what the architect of that pile was in building, Allen is in music. Step aside a little and turn your attention to the ornaments of a pillar of the chapel; you see minute carvings of minute designs, whose chief beauties are deformity or intricacy. Examine all the laborious sculpture; is there any part of it worth the trouble it must have cost the artist, yet how eagerly do children and fools gaze upon these littlenesses. (1 July 1770)

This amounts to a form of artistic manifesto: look at the whole, not the parts, the surface, not the depths. It defines an attitude comparable to that which Susan Sontag celebrates in her "Notes on "Camp"': 'Camp sees everything in quotation marks [...] It is the farthest extension, in sensibility, of the metaphor of life as theater.' Significantly, 
Sontag traces the beginnings of the camp sensibility to the eighteenth century and her delineation of its features - 'a seriousness that fails', 'the spirit of extravagance', 'the glorification of "character" - is almost a dictionary definition of the Chattertonian manner, albeit an explicitly apolitical definition. It even captures the teenage animus behind it: '[Camp] is a feat, of course. A feat goaded on, in the last analysis, by the threat of boredom. ${ }^{32}$ We might think of Chatterton, bored into mischief in the office of the attorney John Lambert on Corn Street, dabbling in necromancy, conjuring up Rowley, leaving a detailed and sharply satirical death-wish to be discovered on his desk:

This is the last Will and Testament of me, Thomas Chatterton, of the city of Bristol; being sound in body, or it is the fault of my last surgeon: the soundness of my mind, the coroner and jury are to be the judges of, desiring them to take notice, that the most perfect masters of human nature in Bristol distinguish me by the title of the Mad Genius; therefore, if I do a mad action, it is conformable to every action of my life, which all savoured of insanity.

Item. If after my death, which will happen tomorrow before eight o'clock, being the Feast of the Resurrection... (14 April 1770)

Chatterton's is an art of grand theatrical gesture. It defies boredom, aims for effect. In this case, the effect was to scare poor Lambert into submission. This was at least the second apparent suicide note the boy had left lying around the office and, together with the rumours of his carrying a loaded pistol around the streets of the city, from time to time aiming it into his mouth and tickling the trigger, it was the last straw: not wanting to have a dead apprentice on his hands, Lambert released Chatterton from his indentures and set him swaggering towards London and legend. 
'What a clash of harmony Allen dashes upon the soul.' It is in this clash of harmony its oxymoronic strangeness, as opposed to the tedious 'littlenesses, flowers, and flourishes' of Broderip - that Chatterton's aesthetic is to be found. Fundamentally disruptive of the classical unities of time, place and action, his work is characterised by its formal and generic promiscuity, its contextual elusiveness, its vernacular impurity and consistent effacement of authorial identity. This latter feature, paradoxically a foregrounding of the fact of authorship, can be seen in the creative overlap that exists between the acknowledged work and the forged work. The Rowleyan voice is not contained, it seeps across, and the acknowledged writings are no less forged - that is, fabricated, pretended, created out of nothing - than their cod-Chaucerian counterparts. ${ }^{33}$ There are the elegies that turn out to be about the elegist, the shifty and self-dramatising letters to family and friends, the non-stick essays assigned to 'Decimus', 'Probus', 'Dunhelmus Bristoliensis' (pen-names were standard at the time, of course: Chatterton was in every sense a product of his age). There are the 'Articles of Belief' that he carried with him to London, including one stating that 'the Stage is the best School of Morality'. There are the suicide notes in search of a suicide, Chatterton putting his own death in quotation marks four months before it actually happened. Every action, every inscription, was an aspect of the work. The love poems, especially, might be seen as enactments of mimetic ambiguity, representations of representation rather than testaments of the heart. There are the lyrics addressed to Miss Hoyland, for instance, at least ten of them, written for Chatterton's friend, John Baker, in South Carolina. And there is an intriguing pair of poems written in 1769, the first addressed to, and the second concerning, Miss Lydia Cotton. 
'To Miss Lydia Cotton' (sometimes known as 'Verses to a Lady in Bristol') is a prickly and confused little hymn to nature which seems unable to stop itself celebrating 'the mimicry of art'. From the opening line, it appears to disparage its own methods 'To use a worn-out simile' - and consistently asserts the superiority of the real over the synthetic: 'Nature untouch'd by art delights - /Art ever gives disgust.' Sounding Blakean, even Lawrentian, in its insistence on authenticity, the poem is less a love poem, more a disquisition on form and the ramifications of form:

In natural religion free,

I to no other bow the knee, Nature's the God I own...

As a proto-Romantic statement of the egotistical sublime, this could scarcely be bettered, and yet the closing stanzas of the poem emphasise not expressive openness but artful subterfuge and cunning: 'Then catch the shadow of a heart, I will not with the substance part.' This is the love lyric as smoke and mirrors, sheer rhetoric almost, conjuring presence from absence, intimacy from distance. It is the erotics of simulation, seduction by proxy.

When Lydia Cotton (not surprisingly) returned the verse to Chatterton, he responded with a poem which, although apparently clear-cut, is similarly elusive. As Taylor has noted, 'A New Song' is 'an appeal to Lydia Cotton disguised as an apology to others that is actually an insult. ${ }^{34}$ Addressed to Alexander Catcott, vicar of Temple Church, Bristol, and Chatterton's erstwhile spiritual mentor, the poem shifts rapidly between theological meditation, slapstick confessional and amatory satire. Initially offering itself in atonement for Chatterton's demolition of Catcott's Treatise on the Deluge (1768) in the recent 'Epistle to Catcott', the poem immediately turns its 
attention to less weighty matters, specifically the boy's ejection from the organ loft of St Mary Redcliffe for making too much noise:
Ah, blame me not, Broderip, if mounted aloft,
I chatter and spoil the dull air;
How can I imagine thy foppery soft,
When discord's the voice of my fair?

We are back to Broderip's 'littlenesses' and the 'clash of harmony', Chatterton's agitated aesthetic of surface and effect. There is no repentance here, only needle and niggle, the excitements of artifice and ambiguity. The ostensible satire on masculine fickleness in the second half of the poem - Miss Cotton's knock-back transforming her, in the poet's eyes, from 'bright queen' into 'hag' - can also be read as a celebration of textual instability, semantic uncertainty:

But would she regain her bright lustre again, And shine in her natural charms, 'Tis but to accept of the works of my pen, And permit me to use my own arms.

Repeating in formal terms the digression that caused the original offence ("from the right way/ My notions and actions run far'), this is not simply a piece of playful carpe diem verse: it remains a critical response to Catcott. Catcott had castigated poetry, Chatterton's poetry specifically, as a devilish pursuit and his treatise, which attempted to reconcile the biblical Flood with the new discoveries of geology, was seen by the young author as antithetical to the poetic imagination, an act of scholarly retrenchment 
on behalf of an embattled orthodoxy. In the 'Epistle to Catcott' Chatterton accused his accuser of cultural barbarism ('You rack each metaphor upon the wheel') and of attempting to force a match between blind faith and empiricism: 'How are our feeble arguments perplexed/ To find out meaning in a senseless text!' Here, with an almost Byronic air of digression and flippancy, he asserts the suppleness of poetry in the face of narrow doctrine.

The clash of harmony at the heart of Chatterton's work is essentially dissident in character and sets itself against the prevailing urge towards clarity and stability, classification, authenticity, progression. This is as true of the acknowledged writings as it is of the more obviously anomalous Rowley forgeries: where the latter are detached, as objects, from the proliferating and standardising culture of print, the former aspire to enter that culture and disrupt it from within. The message of the medium - in McLuhan's terms, its effect ${ }^{35}$ - is subject to distortion, or stalled altogether, not in a gesture of romantic regression, longing for an age before print, but in an act of immediate and essentially political engagement. Chatterton's sustained critique of his environment, what Baudrillard might identify as a 'subversion of the code of the media', reveals itself not only in ambiguity, satire, contradiction and simulation, but also in error. ${ }^{36}$ His work is riddled, literally, with mistakes that effectively confound the precise spirit of the age. Rowley's translations of The Battle of Hastings, for instance, were supposedly based on poems written by the Saxon monk Turgot two hundred years before the Norman invasion of England actually took place. Similarly, 'The Death of Nicou', one of the African Eclogues, builds upon a glaring and repeated example of geographical slippage: ‘On Tiber's bank, Tiber, whose waters glide/ In slow meanders down to Gaigra's side...' Such an error undermines the positivism of typographic literary culture and emphasises the ideological functions of form. At the start of over a hundred years of 'Great Man' European historians, Chatterton's miniature epic of 
African patriotic heroism exposes the conceptual impostures of history. Similarly, his re-routing of the Tiber to Africa leaves an imperial taint on the fabric of exotic pastoral borrowed from William Collins's Persian Eclogues (1742). This accords with the explicit abolitionism of another of Chatterton's African poems 'Heccair and Gaira', in which the title characters recall the coming of the slavers and Gaira prophecies retribution:

In ever-reeking blood this jav'lin dyed

With vengeance shall be never satisfied;

I'll strew the beaches with the mighty dead

And tinge the lily of their features red.

Growing up within sight of Bristol's quayside, Chatterton would have been all too aware of the triangular movements of the slave trade (local goods to the Guinea coast, slaves to the West Indies and the Americas, wealth in abundance to the Bristol merchants) and would have seen 'retired' Africans working as family servants in fashionable Hotwells, Clifton and Kingsdown. Here, with furious prescience, he seems to invert the terms of Enoch Powell's 'rivers of blood' speech from 1968, at the same time anticipating the wartime nationalist rhapsody of Winston Churchill's 'We shall fight on the beaches' (1940). Chatterton was of the same generation as the radical reformer Charles James Fox and of more conservative abolitionists such as William Wilberforce, Thomas Clarkson, and Hannah More. His African Eclogues were a direct influence on Blake's Visions of the Daughters of Albion (1793) and Robert Southey's Poems on the Slave Trade (1797). As Carolyn D. Williams has noted (and the Romantic poets before her), '[his] poetry resonates with political significance'. ${ }^{37}$ 
Challenging postmodern claims on Chatterton's reputation, Peter Ackroyd has emphasised the 'visionary' aspects of the poet's work and written of his mysterious connection 'to the enduring consciousness of the nation'. ${ }^{38}$ Although Ackroyd's sense of that consciousness is less pious and nostalgic - more radical, in fact - than it can often sound in quotation, and although his 1987 novel Chatterton provides an important corrective to the suicidal angel of the nineteenth-century myth-makers, this nationalistmetaphysical reading runs the risk of perpetuating an idea of Chatterton as a melodious antiquarian or eccentric restorer of the original English melody. Open to appropriation by more conservative imaginations than Ackroyd's, it echoes Keats's famous description of Chatterton as 'the purest poet in the English language', tending to simplify a complex and volatile poetic. ${ }^{39}$ Taken as a whole, Chatterton's work is surely the antithesis of purity, and his linguistic fascination derives not from his stripping of the language down to its ethnic essentials, but his exposure of the folly of any such enterprise. Rowleyan English is an anarchic and charismatic mess of quirks, botches, obfuscations and clashing dialects, an attempt by a poet with strong popular and vernacular sympathies to queer the pitch for those standardisers of the national voice and architects of nationhood. The language of the acknowledged writings is similarly resistant to scholarly or official assimilation, a rapid accumulation of influences, voices, genres, perspectives, meanings. The most unreliable of narrators, Chatterton has - as Grevel Lindop suggested back in 1972 - a purity more akin to that attempted by Hugh MacDiarmid than that implied by Keats. ${ }^{40}$ There can be no such thing as a Chatterton purist. The Rowleyans are long since dead.

Chatterton's politics are angry and ill-defined, classically adolescent, but his contradictory and oppositional imagination is possessed by a vision of England as a site 
of prolonged historical trauma. The Rowleyan works are written against the backdrop of the War of the Roses and that period of dynastic conflict provides the source material for such characteristic pieces as 'Elinoure and Juga' and 'Eclogue the First': 'Whanne Englonde smeethynge from her lethal wounde,/ From her galled necke dyd twytte the chayne awaie...' In the case of Rowley's translations of Turgot, of course, the sense of historical cataclysm is multiplied, with centuries of invasion and civil strife being written across or through or against each other. Such an elaborate process of signification, at once fluid and violent, finds a recurrent emblem in Chatterton's favoured image of the 'hygra' or Severn bore. In the drama of Aella, for example, as the eponymous Bristolian chief prepares to resist Celmonde's Danish invaders, this destructive natural phenomenon becomes symbolic of provincial autonomy set in opposition to the lassitude of 'cowarde Londonne':

Wee fyghte notte forre ourselves, botte all the londe.

As Severnes hyger lyghethe banckes of sonde,

Pressynge ytt downe binethe the reyneynge streme,

Wyth dreerie dynn enswolters the hyghe stronde,

Beerynge the rockes alonge ynn fhurye breme...

A comparable image occurs in 'The Parlyamente of Sprytes', where the ghost of Sir Robert Fitzharding (twelfth-century founder of St Augustine's Abbey in Bristol) describes the pressurised period between wars: 'As stopped ryvers alwaies ryse moe hygher,/ And rammed stones bie opposures stronger bee..."

Chatterton is, as Taylor notes, 'a poet of many starts and few finishes', 41 and it is difficult not to regret that the 'History of England' projected in a letter to his mother from London on 6 May 1770 was never completed, perhaps never even begun. In a 
strange way, though, this is what his collected works add up to: a maverick and fragmentary history of the dissenting English imagination, acutely sensitive to conflict and ambiguity, socially engaged, sceptical, often bruisingly indignant and refractory. Like Joyce's Stephen Dedalus, not least in his youthful egotism, Chatterton attempts to forge the uncreated consciousness of his race. ${ }^{42}$ If there is an almost Shakespearean reach to all this, it can hardly be a coincidence that Aella's memorable description of his 'shap-scurged isle' should assonate so neatly, so provocatively, with the 'sceptered isle' of Richard II.

More than any other author (with the possible exception of Anonymous), Chatterton shatters what Michel Foucault identifies as 'the solid and fundamental unit of the author and the work' ${ }^{43}$ He also literalises the idea of the death of the author, as theorised by Foucault himself and, before him, Roland Barthes. '[W]riting is the destruction of every voice,' Barthes states, 'of every point of origin.' He goes on to describe a text as a 'multi-dimensional space in which a variety of writings, none of them original, blend and clash' ${ }^{44}$ And Foucault, referring to writing as 'its author's murderer', claims that the author 'must assume the role of the dead man in the game of writing'. ${ }^{45}$ With these words in mind, it is hard not to think of Sir Henry Wallis's serene image of the death scene - George Meredith's trailing arm, purple trousers, pre-Raphaelite locks - and of Ackroyd's fine novelistic parody:

...his left arm is pressed against his chest while his right arm slips from the bed, the hand clenching and unclenching as if trying to grasp the torn scraps of his writing which are scattered across the floor. Chatterton's neck has been twisted 
by the force of his arsenic convulsions, so that he lies at an unnatural angle on the dank pillow. His left foot is shaking but, eventually, it becomes still. ${ }^{46}$

But the most powerful image of Chatterton is one that the mind can never fully form, an image of his anonymous grave, built over and lost, forever there, forever untraceable, both an absence and a presence like the work itself.

'Poetic strength,' Harold Bloom has written, 'comes only from a triumphant wrestling with the greatest of the dead, and from an even more triumphant solipsism. ${ }^{, 47}$ Chatterton's solipsism, the key to his persistence as a tragic icon, was of a kind that cancelled itself out. His work has been seen as exemplifying the anxiety of influence it is, if nothing else, a colossal patchwork of 'misreadings' of Chaucer, Shakespeare, Milton, Marvell, Dryden, Charles Churchill, Gray, and so on - but the anxiety is implosive: it sucks Bloom's great tradition of Oedipal in-fighting back through a vanishing-point of forgotten figures and marginal disputes, borrowed passions, provinicial epics, anachronistic histories, invented voices. 'An Excelente Balade of Charitie', often thought (probably wrongly) to be the last Rowley poem, is a beautiful re-writing of the story of the Good Samaritan, but it is also a demonstration of how a teenager was able to make himself so belated that he met himself coming back the other way, out of the intermingled futures of Romantic intensity and postmodern surface.

Beneathe an holme, faste bie a pathwaie side,

Which dide unto Seyncte Godwine's covent lede,

A hapless pilgrim moneynge did abide,

Pore in his viewe, ungentle in his weede,

Long bretful of the miseries of neede... 
Exemplifying the 'radical and challenging strangeness ${ }^{48}$ of Chatterton's work, this is lush, rhythmical, familiar, peculiar, massively influential, and almost entirely resistant to critical interpretation. Indeed, it calls to mind the terms of Sontag's essay 'Against Interpretation':

Ideally, it is possible to elude the interpreters in another way, by making works of art whose surface is so unified and clean, whose momentum is so rapid, whose address is so direct that the work can be ... just what it is. ${ }^{49}$

Beyond the evident concern with materialism and social injustice (in which sense it resembles other Rowleyan works, notably 'The Worlde', 'The Ghouler's Requiem' and 'Eclogue the Third'), the critic will find little room for manoeuvre in this meticulously crafted poem. It aspires to "that innocence before all theory when art knew no need to justify itself'.50

That innocence before all theory. Chatterton was no innocent, but he was no theorist either. There are times in this essay when it seems as if he is being rescued from the Romantics and (more urgently) the Victorians, only to be delivered into the hands of the post-structuralists. This is a necessary and appropriate irony, I think, since Chatterton's work constitutes a profoundly Barthesian 'anti-theological' ${ }^{, 51}$ act, proof against both the moral teleologies of the eighteenth and nineteenth centuries, and the arcane excesses of advanced semiotics. Sontag might describe it as the revenge of art upon the intellect. So might Chatterton. He loved books, hated learning, condemning it - in the 'Epistle to Catcott' - as the 'putrid foetus of a barren brain'. This is the Chattertonian paradigm, the Chattertonian paradox. It is apparent in the mischievous, almost Flann O-Brienish way in which he cross-references his fictions (accusing John Iscamme of plagiarising Rowley, for instance) and it was recognised by William Hazlitt 
as far back as 1818 . He meant it as a criticism, but I want to claim it as a recommendation:

The whole secret of the imposture, which nothing but a deal of learned dust, raised by collecting and removing a great deal of learned rubbish, could have prevented our laborious critics from seeing through, lies on the face of it (to say nothing of the burlesque air which is scarcely disguised throughout). ${ }^{52}$

Critical reduction or avoidance of Chatterton begins to look like professional nervousness, ghosted by politics. Hazlitt, at least, seems to have appreciated the antiacademic joke (even if Keats took offence at the laughter) and he was characteristically sharp in decrying the 'abstracted reputation' that had built around the boy in the fifty years since his death. ${ }^{53}$

Barthes has argued that poetic language, like mathematical language, is singular in its ability to resist the blandishments of myth: 'When the meaning is too full for myth to be able to invade it,' he writes, 'myth goes around it, and carries it away bodily. ${ }^{54}$ In the case of Thomas Chatterton, two bodies seem to have been snatched: the physical body, which was not even correctly named in the burial records, ${ }^{55}$ but also, with occasional spectral visitations, the literary body, the body of work, rarely in print, infrequently read, critically untended. For over two hundred years, the only consistently visible aspect of Chatterton has been the myth, and this has fulfilled a function of distraction. Barthes again: 'The function of myth is to empty reality: it is, literally, a ceaseless flowing out, a haemorrhage, or perhaps an evaporation, in short a perceptible absence. ${ }^{56}$ Cleaned up by the Victorians, all but cleared away by the twentieth century, there are now signs that Chatterton's prolonged absence might be coming to an end: the work is appearing slowly from out of the myths of time. As Groom, and others, work to 
restore the remarkable body to view, what becomes increasingly evident is the cultural force of forgery in general, and a uniquely adaptable politics of style.

\footnotetext{
${ }^{1}$ See, for instance, Richard Holmes, 'Thomas Chatterton: The Case Re-opened', Cornhill Magazine, 178 (1970), pp. 200-51, reprinted in Richard Holmes, Sidetracks: Explorations of a Romantic Biographer (London: Harper Collins, 2000).
}

2 E. H. W. Meyerstein, A Life of Thomas Chatterton (London: Ingpen and Grant, 1930), p. 46. For all that it drags in places, disintegrates in others, this is itself a great lost work, long overdue for republication.

${ }^{3}$ Throughout this essay I will use the idea of 'mythology' in the Barthesian sense - that is, to identify the processes by which Chatterton has been 'depoliticized' through the creation of a culturally innocent narrative. Although I am concerned to suggest explicit connections between the formal qualities of the work and the particular radical politics of his day, my understanding of the 'political' in relation to Chatterton might also be clarified through reference to Barthes: 'One must naturally understand political in its deeper meaning, as describing the whole of human relations in their real, social structure, in their power of making the world...' Roland Barthes, Mythologies, trans. Annette Lavers (London: Vintage, 1993), p. 143.

${ }^{4}$ Nick Groom, ed., Thomas Chatterton and Romantic Culture (Basingstoke: Macmillan, 1999), p. 5.

${ }^{5}$ A demonstration of the ambivalent critical attitude to Chatterton is provided by Geoffrey Grigson who, in 1946, wrote 'I don't think any other English poet... began with powers more remarkable', but twentyfive years later came to a rather different conclusion: 'in extenso he remains about the most tedious poet in the English canon.' Chatterton's canonical status has always been illusory, of course, but Grigson himself comments on this 'interesting and curious' reversal of opinion. Geoffrey Grigson, Blessings, Kicks and Curses: A Critical Collection (London and New York: Allison and Busby, 1982), pp. 62-71.

6 Walter Benjamin, 'The Work of Art in the Age of Mechanical Reproduction' (1935), in Illuminations, ed. Hannah Arendt, trans. Harry Zohn (London: Jonathan Cape, 1970), p. 244.

7 Jean Baudrillard, 'Political Economy and Death', in Symbolic Exchange and Death (1976), ed. Mike Gane, trans. Iain Hamilton Grant (London: Sage, 1993), p. 186.

8 Guy Debord, The Society of the Spectacle (orig. 1967; London: Zone Books, 1995). Debord's work is also available through the Situationist International Text Library at http://library.nothingness.org/articles/SI/en/pub contents/4 [accessed 11 August 2011]

${ }^{9}$ Tom Paulin, The Day-Star of Liberty: William Hazlitt's Radical Style (London: Faber and Faber, 1998). Paulin points out that Hazlitt 'was fascinated by self-destructive behaviour' (p. 43) and quotes his distinctly Chattertonian description - from the essay 'Capital Punishments' - of 'becoming reckless of all consequences, porverty, disease, or death, from disappointment in some one thing that the mind is set upon'. The contemporary cult of the beautiful corpse is perhaps most immediately represented by the ' 27 Club', whose most recent member is the singer Amy Winehouse: http://www.forever27.co.uk/forever/ [last accessed 18 August 2011] Although Chatterton missed out on membership of this lugubrious group by a decade, the status of his legendary demise at 17 must make him a founding spirit. 
10 M. H. Abrams, The Mirror and the Lamp: Romantic Theory and the Critical Tradition (Oxford: Oxford University Press,1953). The first chapter, 'Orientation of Critical Theories', in which this idea is discussed, is included in David Lodge, ed., 20th Century Literary Criticism: A Reader (London: Longman, 1972), pp. 1-26.

11 James MacPherson's 'translations' from the Gaelic heroic tradition - in particular from 'Ossian' were published as Fragments of Ancient Poetry collected in the Highlands of Scotland (1760), Fingal, an Ancient Epic Poem (1761), Temora (1763) and Works of Ossian (1765). Hugh Walpole's The Castle of Otranto (1764) was originally published under a pseudonymous cloak, claiming to be a translation by 'William Marshal, Gent' of a $16^{\text {th }}$ century Italian manuscript by 'Onuphrio Muralto'.

12 Nick Groom, 'Thomas Chatterton Was A Forger', The Yearbook of English Studies, 28 (1998), p. 285.

13 Jay David Bolter and Richard Grusin, Remediation: Understanding New Media (Cambridge, Mass., and London: MIT Press, 1999). For Bolter and Grusin, and for McLuhan before them, remediation designates far more than the simple 'progressive' evolution from one medium to its successor. The history of media development is, they argue, a history of emergence, assimilation, challenge, reaction, adaptation and convergence, rather than one of sequential obsolescence. Remediation describes the 'complex kind of borrowing in which one medium is itself incorporated or represented in another medium' (p. 45). See Marshall McLuhan, Understanding Media: The Extensions of Man (orig. 1964; London and Cambridge, Mass: MIT Press, 1994), pp. 48-55.

14 Ibid., p. 171.

15 Ibid., p. 173. See also Marshall McLuhan, The Gutenberg Galaxy: The Making of Typographic Man (orig. 1962; London: Routledge and Kegan Paul, 1962).

${ }^{16}$ My primary source for Chatterton's work has, inevitably, been Donald S. Taylor and Benjamin B. Hoover's two-volume edition of The Complete Works of Thomas Chatterton (Oxford: Clarendon Press, 1971): all quotations have been taken from this definitive piece of scholarship. In writing the present study, however, I have also referred to its bowdlerising predecessor, Walter W. Skeat's Poetical Works of Thomas Chatterton, 2 vols. (orig. 1875; London: George Bell and Sons, 1891), and to two selected editions, John Richmond's Poetical Works of Thomas Chatterton (London: Walter Scott, 1885) and Grevel Lindop's Thomas Chatterton: Selected (Oxford: Carcanet Press, 1972). Other notable editions are Thomas Tyrwhitt's Poems, supposed to have been written at Bristol, by Thomas Rowley and Others, in the Fifteenth Century (London: T. Payne and Sons, 1777) and Robert Southey and Joseph Cottle's The Works of Thomas Chatterton, 3 volumes (London: T.N. Longman and O. Rees, 1803).

${ }^{17}$ William Blake's illuminated works - mixing image, colour, script, printed using relief-etching, individually hand-coloured, but most often reproduced now in plain text print versions - offer a fascinating counterpart to Chatterton's Rowley pieces in this respect.

${ }^{18}$ N. Katherine Hayles, Writing Machines (Cambridge, Mass., and London: MIT Press, 2002, p. 25.

${ }^{19}$ Talan Memmott, Lexia to Perplexia (2000), available at http://collection.eliterature.org/1/works/memmott lexia to perplexia.html [last accessed 15 August 2011]. Tom Phillips, A Humument: A Treated Victorian Novel (orig. 1970; London: Thames and Hudson, 2004). Revised editions of Phillips' ongoing textual-graphical 'remix' of William H. Mallock's novel $A$ Human Document (1882) were published in 1986, 1998 and 2004. The official website - with slideshow - is at http://humument.com/ [last accessed 15 August] - and from November 2010 the work has been 
downloadable as an iPhone app. Mark Z. Danielewski, House of Leaves (London and New York: Random House, 2000).

20 Benjamin, Illuminations, pp. 219-53.

${ }^{21}$ Hayles, Writing Machines, p. 130, p. 22

22 "For the "content" of any medium is like the juicy piece of meat carried by the burglar to distract the watchdog of the mind.' (McLuhan, Understanding Media, p. 18) With a fine irony, this is itself an example of content-based remediation, adapting as it does T.S. Eliot's own discussion of meaning in The Uses of Poetry and the Uses of Criticism (1933): "The chief use of the "meaning" of a poem, in the ordinary sense, may be [...] to satisfy one habit of the reader, to keep his mind diverted and quiet while the poem does its work upon him: much as the imaginary burglar is always provided with a bit of nice meat for the house-dog.' T.S. Eliot, Selected Prose, ed. John Hayward (London: Penguin Books, 1953), p. 93. In relation to Chatterton's work, of course, the process has been gloriously kinked, with issues of meaning and formal operation becoming mutually and endlessly distracting.

23 Quoted in Meyerstein, p. 86.

24 Christopher Caudwell, Illusion and Reality: A Study of the Sources of Poetry (London: Lawrence and Wishart, 1937), pp. 86-7 et passim.

25 See Nick Groom, The Forger's Shadow: How Forgery Changed the Course of Literature (London: Picador, 2002), pp. 154-62.

${ }^{26}$ I have written previously about Chatterton's background in relation to his radical vision. See Ivan Phillips, 'Beyond the marvellous boy - Thomas Chatterton's influence on the Romantics', The Times Literary Supplement, 18 September 1998, pp. 17-18.

27 Donald S. Taylor, Thomas Chatterton's Art: Experiments in Imagined History (Princeton: Princeton University Press, 1978), p. 176.

28 Louise J. Kaplan, Thomas Chatterton: The Family Romance of the Imposter-Poet (Berkeley: University of California Press, 1989), p. 3.

29 Ibid., p. 161.

30 Meyerstein, p. 97.

31 Groom, 'Thomas Chatterton Was A Forger', p. 276.

32 Susan Sontag, Against Interpretation and Other Essays (New York: Delta Books, 1967), pp. 275-92.

33 The semantic fluctuations and subtleties of words such as 'forgery', 'copy', 'counterfeit', 'plagiarism' and 'original' are sharply examined in Groom, The Forger's Shadow, pp. 16-50.

34 Taylor, Thomas Chatterton's Art, pp. 258. 
35 'For the "message" of any medium or technology is the change of scale or pace or pattern that it introduces into human affairs.' McLuhan, Understanding Media, p. 8.

36 Jean Baudrillard, 'The Masses: The Implosion of the Social in the Media', Selected Writings, ed. Mark Poster (Cambridge: Polity Press, 1988), p. 208.

37 Carolyn D. Williams, “'On Tiber's Banks": Chatterton and Post-Colonialism', in Groom, ed., Thomas Chatterton and Romantic Culture, p. 48.

38 Peter Ackroyd, Preface to Groom, ed., Thomas Chatterton and Romantic Culture, pp. 1-2.

39 John Keats to John Hamilton Reynolds, 21 September 1819. See Hyder E. Rollins, ed., The Letters of John Keats, vol. 2 (Cambridge, Mass: Harvard University Press,1958), p. 167.

40 Lindop, Thomas Chatterton: Selected, p. 23.

41 Taylor, Thomas Chatterton's Art, p. 7.

42 James Joyce, A Portrait of the Artist as a Young Man (orig. 1916; Harmondsworth: Penguin Books, 1975), p. 253.

43 Michel Foucault, 'What is an Author?', The Foucault Reader, ed. Paul Rabinow (Harmondsworth: Penguin Books, 1991), p. 101.

44 Roland Barthes, 'The Death of the Author', Image-Music-Text, ed. Stephen Heath (London: Fontana, 1977), p. 142, p. 146.

${ }^{45}$ Foucault, 'What is an Author?', p. 102.

46 Peter Ackroyd, Chatterton (London: Sphere Books, 1988), p. 230.

47 Harold Bloom, 'Poetic Origins and Final Phases' - the first chapter of his study A Map of Misreading (Oxford: Oxford University Press, 1975) - included in David Lodge (with Nigel Wood), ed., Modern Criticism and Theory (orig. 1988; London and New York: Longman, 2000), p. 218.

48 Taylor, Thomas Chatterton's Art, p. 4.

49 Sontag, p. 11. Sontag identifies cinema as being capable of such artworks and it seems significant that Taylor should have written of Chatterton's 'verbal cinematography' (Thomas Chatterton's Art, p. 84).

${ }^{50}$ Sontag, p. 4.

51 Barthes, 'The Death of the Author', p. 147.

52 William Hazlitt, Lectures on the English Poets/ The Spirit of the Age, ed. A. R. Waller (orig. 1818, 1825; London: J. M. Dent and Sons, 1934), p. 124.

53 For Keats's disappointed reaction to Hazlitt's comments on Chatterton, see Robert Gittings, John Keats (orig. 1968; Harmondsworth: Penguin Books, 1971), pp. 288-9. Gittings speculates that Hazlitt's 
qualifying remarks at the start of his next lecture were addressed directly to Keats: 'What I meant was less to call into question Chatterton's genius, than to object to the common mode of estimating its magnitude by its prematureness. The lists of fame are not filled with the dates of births or deaths...' (Hazlitt, p. 123). As so often, Hazlitt seems to have been years ahead of the critical culture in which he lived.

\section{${ }^{54}$ Barthes, Mythologies, p. 132.}

$55 \mathrm{He}$ was entered in the register as "William Chatterton Brook's Street 28". See Groom, The Forger's Shadow, p. 4.

56 Barthes, Mythologies, p. 143. 